\title{
ARTHUR STANLEY WOHLMANN, THE FIRST GOVERNMENT BALNEOLOGIST IN NEW ZEALAND
}

\author{
Ralph H. Johnson
}

\section{INTRODUCTION}

Geologically, New Zealand lies along the intersection of two of the earth's major plates and therefore earthquakes, volcanoes, and hot springs are widespread. The original inhabitants, the Maori, were aware of the therapeutic value of hot-pools and, as Europeans settled on the islands in the nineteenth century, many travellers commented circumstantially on the potential of the pools, both therapeutically and for extending tourism. Eventually, in 1902, the New Zealand government created a new national medical appointment, to be held in a new department, that of Tourist and Health Resorts, a title that indicated the two major projects that its establishment was to encourage. The post was given the title of Government Balneologist and the activities of the first holder, Arthur Stanley Wohlmann, provide the basis for this account, which also discusses his approach to therapy compared with that of similar physicians practising in Britain.

The clinical applications of water, hydrotherapy, or balneology 1 as it was sometimes called, receives little attention at present among those trained in the medical traditions of Western Europe although clinicians in Eastern Block countries continue to advise its use. ${ }^{2}$ Spas that had been developed around mineral springs believed to have healing powers are now largely neglected in Britain, Germany, and France, countries which had many such establishments during the nineteenth century. ${ }^{3}$ A similar pattern occurred in New Zealand, though the developments took place rather later; the subject of this article is part of that story. 4

Ralph H. Johnson, MA, MD, DM, D.Sc., D.Phil., Director of Postgraduate Medical Education and Training, Oxford University, and Professorial Fellow, Wadham College, Oxford OX1 3PN.

\section{ACKNOWLEDGEMENTS}

This paper has depended upon records in the National Archives, Wellington, and the Rotorua Muselım. In addition, details of Wohlmann's career have been obtained from Hereford Grammar School, Guy's Hospital, the Royal Society of Medicine, and the British Medical Association, as well as several correspondents in England and New Zealand.

\footnotetext{
${ }^{1}$ Balneology: from the Latin balneum (bath), with the Greek-derived suffix indicating a department of knowledge. Balneology was used as the title for spa therapy with mineral waters, and was distinguished from hydrotherapy, but by 1911 the latter term was accepted for all forms of treatment with water. R. F. Fox, 'Outlines of medical hydrology', Proc. R. Soc. Med., 1911, 4: 63-80.

2 W. A. Thomson, Spas that heal, London, Adam \& Charles Black, 1978.

${ }^{3}$ E. S. Turner, Taking the cure, London, Michael Joseph, 1967.

${ }^{4}$ Hot spring use in New Zealand has been reviewed by I. Rockel, Taking the waters, Wellington, Government Printing Office, 1986.
} 


\section{The first Government Balneologist in New Zealand}

Two approaches to hydrotherapy developed and can be identified, and the title of the New Zealand department to which Wohlmann belonged delineates them. First, medical advisers and physicians became increasingly interested in its therapeutic value. Various treatments were recommended with water, applied to the body in baths, or douches, or as steam, or taken by mouth. In the decades immediately prior to 1800 , water came to be considered both a less costly and also a therapeutic alternative to the more conventional treatments of the time. For example, in the many editions of his book Primitive physick, ${ }^{5}$ John Wesley propounded his views. "The medicines being used are too dear for poor men to buy and too hard for plain men to understand." He stated that they had "too many ingredients" which only "swelled the apothecary's bill. Nay, possibly, on purpose to prolong the distemper that the doctor and he may divide the spoil." Among Wesley's major rules was the use of water both by mouth and in cold bathing. He listed over 60 conditions that he considered could be cured by these means, including such neurological problems as convulsions, palsies, and St Vitus' dance, and such cardiac disorders as dropsy and palpitations.

Throughout the next 150 years many authors wrote about the therapeutic importance of hydrotherapy, even to the point of proposing that it is the "only true therapy". 6 Arguments developed about techniques that should be used. One of the last textbooks to propound its importance was by the medical author Simon Baruch, who had written textbooks on hydrotherapy in 1893 and 1898. In his last book, $A n$ epitome of hydrotherapy, ${ }^{7}$ published in 1920 , he recorded that he had held a Chair of Hydrotherapy at the College of Physicians and Surgeons of Columbia University, but had to relinquish it "unavoidably" and "regrettably". He hoped that his readers would "resolve to restore hydrotherapy to the regular curriculum" and that there would be an understanding that it is "an important integral part of our materia medica requiring the same careful preparation, exact dosage and precise administration as do drugs".

The New Zealand government was, however, more interested in hydrotherapy's potential as a tourist attraction than in the therapeutic powers attributed to it. When Arthur Wohlmann was appointed Government Balneologist, the rich and famous in Europe followed the ruling classes to such diversions as yachting at Cowes or the European spas. ${ }^{8}$ New Zealand politicians were attracted by the wealth that seemed to be amassed through the spas, rather than by concern for treatment of the sick, but failed to realize that the success of the European spas depended to a great extent upon amusements provided by, for example, casinos and eating places, not to mention the possibility of dubious assignations. These were all important attributes that would be difficult to emulate. Visits to spas were for a few weeks, not for a few months, and travelling to New Zealand was not a practical venture on an annual basis in the way that visits to European spas were.

\footnotetext{
5 John Wesley, Primitive physick, or an easy and natural method of curing most diseases, London, T. Trye, 1747 (the quotations are taken from the 1780 edition).

${ }^{6} \mathrm{H}$. Francke, Outlines of a new theory of disease applied to hydrotherapy, showing that water is the only true remedy, transl. Robert Barkie, London, Longman, Brown, Green \& Longmans, 1849.

${ }^{7}$ S. Baruch, An epitome of hydrotherapy, for physicians, architects and nurses, Philadelphia and London, W. B. Saunders, 1920.

8 J. Wechsberg, The lost world of the great spas, New York, Harper \& Row, 1979.
} 
The attempt to promote New Zealand in this way was not a rapidly instituted decision, however ill-advised it was. The idea had been developed over several years. In 1897 the Premier of New Zealand, Richard Seddon, met the New Zealand Agent-General in London, W. P. Reeves, who, incidentally, had previously been his political rival, and invited him to prepare a report on the possibility of increasing the number of visitors to the New Zealand hot springs. The result was a memorandum addressed to the Premier on 'Our Thermal Springs and Their Development' and in it Reeves was enthusiastic about the opportunities for using "waters of undoubted healing power". 9

The potential value of the thermal springs as a creator of revenue had been proposed earlier, in 1870, by a former Premier, William Fox, who said that they might prove a source of great wealth to the colony. Some twelve or so years later, the town of Rotorua was founded. Rotorua is in the North Island of New Zealand, south east of Auckland. Close by is Te Aroha, a much smaller settlement, also with hot springs. The development of both depended upon the railway. For example, the railway reached Te Aroha in 1885 and there followed in 1887 the first description of the place as a spa. A proposal was developed for a private company to construct at Te Aroha a sanitorium for treatment of patients by "packing, galvanism, medical rubbing [massage] etc., by skilled operators". 10 The railway reached Rotorua at the end of 1894.

THE APPOINTMENT OF THE FIRST GOVERNMENT BALNEOLOGIST:

ARTHUR STANLEY WOHLMANN ${ }^{11}$

As a result of the Agent-General's report in 1897, the possibility of New Zealand government involvement in the development of the hot springs was considered in the New Zealand House of Representatives in the same year. As a result, the AgentGeneral was asked to select a suitable candidate to take charge of the organization of the thermal springs district around Rotorua. The first choice, who claimed to have been physician to HRH the Prince of Fürstenberg, declined the New Zealand post because he also wished to receive fees for professional consultations. The Government had not agreed and no appointment was made. ${ }^{12}$

In 1899 the Minister of Lands reported that the bath houses at Rotorua were considerably decayed and it would be necessary to erect new ones very soon. ${ }^{13}$ There was continued pressure on the government to improve facilities at Rotorua ${ }^{14}$ and it must have been with some relief that, in 1902, it was reported that a balneologist had

${ }^{9}$ W. P. Reeves, 'Our thermal springs and their development', Memorandum for the Hon. the Premier, Richard Seddon, 1897 (16 pp.), Department of Lands and Survey file, National Archives, Wellington. In spite of Reeves's interest in the commercial aspect of the hot springs, he had been New Zealand's first Minister of Labour and had published the first study of socialism and communism there. He set up co-operative "labour farms" for the unemployed, which soon ceased to function.

${ }^{10}$ A. Wright, Te Aroha, New Zealand: a guide for invalids and visitors to the thermal springs and baths, Te Aroha, Hot Springs Domain Board, 1887 (34 pp.).

1 Wohlmann (pronounced "Wellman") changed his surname to Herbert in 1915.

12 'Balneologist for Rotorua': question by Herries (MP, Bay of Plenty); reply from J. McKenzie (Minister of Lands). New Zealand Parliamentary Debates, 1898, 102: 361.

13 'Hot springs district balneologist': question by Herries (MP, Bay of Plenty). Ibid., 1899, $104: 425$.

14 'Rotorua bath-houses': question by Witheford (MP, Auckland City). Ibid., 1900, 111: 599. 


\section{The first Government Balneologist in New Zealand}

at last been appointed to the colony. Arthur Stanley Wohlmann was chosen from among 43 applicants by the Agent-General in company with Dr Parkes Weber, among the foremost private physicians in London then concerned with advising patients on the most appropriate European spa for their complaint. ${ }^{15}$ All his referees' reports were reproduced in the published records of the New Zealand House of Representatives at the time. ${ }^{16}$ It was apparent that Dr Wohlmann had no experience of European spas for he was sent on a two-week visit to Continental health resorts prior to embarking for New Zealand. He did not seem too keen to experience the treatments personally as he reported "I had two massage baths myself while elsewhere two attendants were bathed and massaged for me". ${ }^{17}$

Arthur Wohlmann (plate 18) had entered Guy's Hospital Medical School in London in June 1885 and gained his Bachelor of Medicine degree in October 1891. He was clearly an able student and held two house appointments at Guy's before proceeding, in only one year, to the degree of Doctor of Medicine in $1892 .{ }^{18}$ By mid-1893 he had moved to the Royal Mineral Water Hospital at Bath as Resident Medical Officer and he was still in practice at Bath immediately prior to moving to New Zealand. By the time he was appointed he was 34 years old, married, and had a 3-year-old daughter.

\section{THE DEPARTMENT OF TOURIST AND HEALTH RESORTS}

Arthur Wohlmann's appointment as Government Balneologist coincided with the decision by the New Zealand government to establish the new Department of Tourist and Health Resorts. This was the responsibility of Joseph Ward, a future Premier. The name of the new department indicates the great hopes that the administration had for the future of the thermal spas; "health resorts" would form part of its title for most of the period until 1951. The position of Government Balneologist was retained by the government until 1957. It was held by Wohlmann (1902-19), and then by J. C. Duncan (1919-42) and A. J. M. Blair (1942-57), after whom the appointment lapsed.

The Department's official publications indicate the importance that it attached to the duties of the Balneologist and their potential for developing the thermal areas. James Cowan, in his account of New Zealand written for the Department, was eulogistic about Rotorua:

As a spa, Rotorua has no superior in the world. These "living waters" are responsible for many a wonderful cure. Cripples throw away their crutches after a few weeks' bathing, the gouty man regains his health ... ${ }^{19}$

\footnotetext{
${ }^{15}$ Sir H. Weber and F. Parkes Weber, Climatotherapy and balneotherapy: the climates and mineral water health resorts (Spas) of Europe and North Africa including the general principles of climatotherapy and balneotherapy and hints as to the employment of various physical and dietetic methods being a 3rd edition of 'The mineral waters and health resorts of Europe', London, Smith Elder, 1907.

${ }^{16}$ Department of Tourist and Health Resorts, First annual report, House of Representatives, Appendix to the Journals, 1902 (22 pp.).

17 Ibid.

${ }^{18}$ E. J. Robinson, personal communication on Wohlmann's University of London record, from the University of London Senate House Library, 1987.

19 J. Cowan, New Zealand or Ao-Tea-Roa: its wealth and resources, scenery, travel routes, spas and sport, Wellington: New Zealand Department of Tourist and Health Resorts, 1908, pp. 118-19.
} 
THE CONTRIBUTION MADE BY WOHLMANN, 1902-1919

Arthur Wohlmann apparently settled down happily into his new environment. In his first papers on Rotorua ${ }^{20}$ he compared the climate to that of the "old country" very favourably:

Blue sky tends to replace the sober grey; there is less fog, more light, more air. Distant objects show up with a distinctness almost unknown in England. It is an air which exhilarates, sharpens the appetite and the zest of living.

A notable omission was any comment on the familiar Rotorua smell due to $\mathrm{H}_{2} \mathrm{~S}$ in the atmosphere! He also maintained enthusiasm for his tasks, one based on the importance he considered that the thermal springs of New Zealand would have: "The springs of this country would suffice not for ourselves but for a continent ... in the extraordinary variety of mineral water ... they would easily eclipse any others in existence." 21 His duties were to develop the Rotorua Spa, to care for patients, and to advise on spas throughout the country. Early on he was of the opinion that only one spa should be brought "thoroughly up to date" and that should be Rotorua. 22

Rotorua had the advantage of both acid waters (the Priest and Postmaster baths) and alkaline waters (Rachel water). Wohlmann described the baths at that time as being in an advanced state of decay; the Priest Baths were "More like pigstys than places for Christians to bathe in." 23 In 1903 he set about designing new bath buildings. He wanted an environment in which he could practise greater scientific precision; the baths were only to be used according to his prescription. The final bath house, known today as the "Tudor Towers" in the Government Gardens at Rotorua, closely follows his original design (plate 19). The building material was to be wood used in the "old English half-timbered style of architecture". The buildings were to run due north and south, facing west, with an octagonal tower in the centre to form a lantern light to the central hall, which would have a tiled floor and fountain, with palms and ferns around it. One side was for gentlemen and the other for ladies. In each there were to be private deep and shallow baths and a "douche-massage establishment". In that area there were to be a whole range of douches including an Aix massage (massage by either one or two operators while powerful douches play on different parts of the patient), a Scottish douche (alternative jets of hot and cold water under high pressure), a needle bath, a spinal douche, a lumbar douche, and ascending douche, although no explanation is given of that treatment! At one end of the room there was to be a switchboard at which the operator could control all the douches. ${ }^{24}$

\footnotetext{
20 'The mineral waters and the health resorts of New Zealand', pt. 1, (review of Wohlmann's pamphlet on Rotorua), Taranaki Herald, 24 October 1904; A. S. Wohlmann, 'Rotorua and surrounding districts, Te Aroha, Hamner', New Zealand Official Year Book, Wellington, Government Printer, 1904, pp. 572-84; idem, The mineral waters and health resorts of New Zealand, pt. 1, Rotorua, pt. 2, Te Aroha, pt. 3, Hamner, Wellington, Government Printer, 1905.

21 'Report of Government Balneologist', Department of Tourist and Health Resorts, Second annual report, House of Representatives, Appendix to the Journals, 1903, app. 1.

22 Ibid.

${ }^{23}$ A. S. Wohlmann, unpublished letters from 1902, 1904, 1909, and 1910 to T. E. Donne, General Manager (or Acting Manager), Department of Tourist and Health Resorts. National Archives, Wellington.

24 'Report', op. cit., note 21 above.
} 
It would be possible to give 14 deep, 42 shallow, 12 mud, 4 electrical, and 4 local vapour baths as well as 8 massage-douches all at the same time. He suggested a 12-hour working day, so that 1,000 bathers a day could be accommodated. In addition 5 patients could take sun baths. Inhalations could be conducted in a separate room, where 10 patients suffering from bronchitis, asthma, or laryngitis could inhale nebulized Rachel water. Around the wall of that room were to be little boxes "like compartments, placed for the public in telegraph offices" from which "you may receive a special spray to the throat, nose and face". ${ }^{25}$ Wohlmann also considered the development of golf links and dreamed of white-sailed yachts and Maori war canoes upon the lake.

In designing the building with the government architect, J. Wrigley, Wohlmann recorded the considerable help of Mr Collett, the Clerk of Works at Rotorua, who had many opinions about how to build there. Many of his views led to practical changes in design. It was $\mathrm{Mr}$ Collett who stated that wood pulp plaster should not be used; subsequent problems would have been avoided had this opinion been heeded.

By 1908 the bath establishment was complete enough to open. The cost was estimated by Wohlmann to have been $£ 30,000{ }^{26}$ By 1909 the new baths were in action but the total bath receipts increased by only $£ 612$ that year. This small increase was a poor return on the original capital, but this was not mentioned at all. The actual number of overseas visitors were only 95 from Australia, $\mathbf{4 0}$ from Great Britain, and 35 from all other countries. ${ }^{27}$ The new bath house never matched the financial hopes that had led to its building.

Problems began to occur within months with both the piping, because of the acid water, and also with the finish of the building. Even in July 1909, Arthur Wohlmann drew attention to the fact that pulp plaster on the walls and ceiling was showing serious cracks and that it had come away from the cement plaster beneath. By December 1909 the plaster was described as "coming away in large pieces and to be stained and unsightly". In June 1910 he reported that "falling plaster was liable to injure bathers and leave the Government open to a claim for heavy damages". ${ }^{28}$ Within two years several of the areas in the baths were requiring resealing and relining. Such were the difficulties that developed over the building as a result of the acid environment of Rotorua and "the original blunder of plastered ceilings" that by the late 1920s and the early 1930s it was suggested that demolition and reconstruction of the main bath building should take place.

Throughout the term of his appointment Wohlmann reported on thermal springs elsewhere in New Zealand. The General Manager of the new Department of Tourist and Health Resorts was keen to have publications available about the other major spas, Te Aroha and Hamner, as well as Rotorua. ${ }^{29}$ Wohlmann, in writing these pamphlets in the first two years after his arrival, therefore had to visit these spas and

\footnotetext{
25 Ibid.

26 'Report of Government Balneologist', Department of Tourist and Health Resorts, Seventh annual report, House of Representatives, Appendix to the Journals, 1908, app. 2.

27 'Report of Government Balneologist', Department of Tourist and Health Resorts, Eighth annual report, House of Representatives, Appendix to the Journals, 1909, app. 2.

${ }^{28}$ Wohlmann, letters, op. cit., note 23 above.

${ }^{29}$ Idem, Mineral waters, op. cit., note 20 above.
} 
be able to describe them. About Hamner, in the South Island, he wrote, "I do not think the picture [Hamner plains] would do very well, as it makes a desolate scene one would like to get away from".$^{30}$ Many minor springs were also the subject of his visits and his comments. In 1904, after going to Paeroa in North Island, on a private visit, he wrote: "It approximates very closely to some of the most famous table waters of Europe. I am afraid however, that the universal use of tea in the colony makes the demand for such a water very limited." ${ }^{31}$ In 1906 he visited Te Puia in the East Cape of North Island and recommended the purchase of its springs although this only took place several years later. It must have been obvious to him, when he described its access, that it would be many years, if ever, before it reached any prominence. $\mathrm{He}$ wrote,

By coach from Gisbourne, 65 miles . . largely along the seashore on hard sands ... At one spot the coach has to cross a ledge of slippery rocks several hundred yards in breadth. The going here is horribly bumpy and impracticable for one seriously ill, and distinctly dangerous... ${ }^{32}$

Gradually exasperation crept into his correspondence about the various springs:

As to which springs the Department should get a lien over depends upon the general policy of the Government in the future in regard to the thermal springs. There are several hundreds of springs dotted about the country many of which I have visited and the question is, does the Government think it advisable to pass a special act placing a lien on all springs or not? ${ }^{33}$

Arthur Wohlmann also showed concern for his clinical duties and repeatedly pressed the government about upgrading the sanatorium and building a hospital at Rotorua. For example, he commented, "I have to accommodate surgical cases in tents ... The question of hospital accommodation for the Rotorua District must very soon be seriously faced." 34 Although the sanatorium was upgraded occasionally it was never rebuilt and it eventually closed in 1948.

In his first ten years in New Zealand, Wohlmann was only mentioned once in the journal of its Medical Association, through an article he produced when its Annual Meeting was held in Rotorua in 1911.35 However, Wohlmann's pamphlets were widely distributed and in 1914 he produced an entire book dealing with the Mineral waters and spas of New Zealand. ${ }^{36}$ It described his results with 593 patients he personally treated in the previous three years at the new baths at Rotorua, as will be explained below.

${ }^{30}$ Wohlmann, letters, op. cit., note 23 above.

${ }^{31}$ Ibid.

32 Ibid.

${ }^{33}$ Idem, unpublished letter to the Director, Department of Tourist and Health Resorts, 16 June 1911. National Archives, Wellington.

34 'Report of Government Balneologist', Department of Tourist and Health Resorts, Fifth annual report, House of Representatives, Appendix to the Journals, 1906, app. 2.

${ }^{35}$ A. S. Wohlmann, 'The acid sulphur waters of Rotorua', NZ med. J., 1911, 9: 36-45.

${ }^{36}$ Idem, Mineral waters and spas of New Zealand, Wellington, Government Printer, 1914 (155 pp.). 


\section{The first Government Balneologist in New Zealand}

Soon after the outbreak of the First World War, Wohlmann, like many others who had Germanic surnames, changed his name, in his case to Herbert, his mother's maiden name. After 1915, until his return to Britain in 1919, Arthur Herbert was to spend much of his time concerned with the rehabilitation of returned soldiers.

The Ministry of Defence records in Wellington about Dr Herbert include the parchment of his appointment as a Surgeon Lieutenant in the Volunteer Forces in Great Britain between 1900 and 1902 . His volunteer service was to prove valuable for him for, in 1915, he applied for military rank as Medical Superintendent of the newly-built Convalescent Hospital of Rotorua. In a beautifully-worded letter he explained that he sought the rank to define his relationship to his military colleagues, not to gain any advantage to himself. In an article in the New Zealand Medical Journal in December 1916 he described his treatment ${ }^{37}$ and in 1918 the Government printer produced the first (and only) volume of his Military physical orthopaedics. ${ }^{38}$ Both publications were largely devoted to the use of splints and of elastic to simulate the action of muscles. He was awarded an OBE for these services, rather than for his civilian work. ${ }^{39}$

In 1918 Arthur Herbert indicated that he intended to resign. He had decided to return to Britain and he left New Zealand in May 1919. The high esteem in which he was regarded in Rotorua is shown by a petition, signed by over 140 people who had been his patients and colleagues:

We, the undersigned patients and staff of the Sanatorium, heard with feelings of the
deepest regret and alarm of the resignation of Lieutenant Colonel Herbert. We feel
that his unique knowledge of the medicinal and curative value of the waters of the
district, combined with his great personal sympathy for those who come under his
charge, makes him an ideal medical officer for these institutions.

After his return to London he used his photographs, his earlier pamphlets, ${ }^{41}$ and his 1914 book $^{42}$ to produce a detailed account of the opportunities for spa treatment in New Zealand. It was published in $1921^{43}$ and a New Zealand reviewer highlighted Herbert's claims that the waters of Rotorua have a potency and therapeutic effect undreamed of in England and unequalled through the world. ${ }^{44}$ It must be questioned, however, whether the book influenced many travellers for, as Herbert noted in its introduction, "There comes to all of us a time in which the illusions of youth are lost. The author labours under no illusions that a book such as this will be read through from beginning to end, save by the heroic few." Herbert took up private practice in

\footnotetext{
${ }^{37} \mathrm{~A}$. S. Herbert, 'The physical treatment of wounded: elastic support in muscular paralyses', $N Z$ med. $J$., 1916, 15: 246-57.

${ }^{38}$ Idem, Military physical orthopaedics, pt. 1: Gunshot wound of nerve, Wellington, Government Printer, 1918 (136 pp.).

${ }^{39}$ Records in the Ministry of Defence, Wellington, regarding Lt. Col. (temp.) A. S. Herbert, RNZMC.

40 Ibid.

${ }^{41}$ Op. cit., note 20 above.

42 Op. cit., note 36 above.

43 A. S. Herbert, The hot springs of New Zealand, London, H. K. Lewis, 1921 (284 pp.)

44 Unsigned review, NZ med. J., 1922, 21: 33-4.
} 
Kensington, London when he returned to Britain. He died on 3 March 1944, and his time in New Zealand only merited two lines in the obituary published a few days later in the British Medical Journal. ${ }^{45}$

The post that he was the first to hold lingered on and was eventually abolished in 1957, a few years after the Rotorua bath-house had been transferred to the Department of Health. It subsequently became an area museum.

FACTORS INFLUENCING THE SUCCESS, OR OTHERWISE, OF WOHLMANN'S EFFORTS

Arthur Stanley Wohlmann was a pioneer. It could therefore be possible that his approaches to clinical practice and the procedures he developed would be primitive compared with medical treatment and management in Britain. However, although the methods he described in his various writings appear archaic to present-day doctors, they were in line with those adopted by physicians in the establishments he was trying to emulate.

There are at least three explanations for his success in matching what was occurring in Britain. First must be the support given to him by the New Zealand government through the building of the new hydrotherapy establishment at Rotorua. This was the largest public-work investment to attract tourists up to that time. Second, Rotorua was on an established tourist route for visitors travelling through New Zealand during the first decade of the twentieth century. Third was the stalwart approach that he took to his duties and the way that he attempted to analyse his patients and investigate them scientifically. The first of these has already been discussed; the next two sections give details of the other two issues.

\section{CHANGES IN TOURISM}

The tourist potential of the hot springs area depended upon the completion of the Rotorua branch of the New Zealand Railway System in 1898. At that time the railway had reached Taumarunui on the route south from Auckland to Wellington. Even so, Thomas Cook \& Son recommended that the most popular overland route from north to south was that via Rotorua, Wairakei, and the Wanganui River (plate 20). Their 1905 handbook was entitled New Zealand as a tourist and health resort, ${ }^{46}$ whereas guide-books from a decade or more earlier, for example the Orient Line guide ${ }^{47}$ make no mention of Rotorua or of thermal spas. After arriving at Rotorua, a coach was taken through such hot-water region sites as Wairakei, to Taupo. Then a steamer was boarded to cross Lake Taupo to Tokaanu, from which a coach took the tourist via Waiouru to Pipiriki, from where the traveller journeyed by river-boat to Wanganui, and then by rail again to Wellington. All recommended tours through North Island from Auckland included Rotorua, although one by rail involved returning to Frankton and transferring to a train to Taumarunui and thence continuing by river-boat on the Wanganui river. This route foreshadowed the eventual route that bypassed Rotorua, for in 1908 the main trunk line from Auckland

\footnotetext{
45 Br. med. J., 18 March 1944, i: 408.

${ }^{46}$ New Zealand as a tourist and health resort, 5th ed., Auckland, Thos. Cook \& Son, 1905.

47 W. J. Loftie (ed.), Orient Line guide: chapters for travellers by sea and by land, 3rd ed., London, Sampson Low, Marston, Searle \& Rivington, 1888.
} 


\section{The first Government Balneologist in New Zealand}

to Wellington was completed and it was possible to make rapid progress southwards without the discomfort of long coach journeys on the section south of Rotorua, as had previously been recommended. The completion of the Bath House in the same year as the trunk railway was, however, important in retaining interest in going to Rotorua, particularly by those wishing to take the waters, but the town was no longer on the major through route.

\section{WOHLMANN'S CLINICAL AND RESEARCH WORK}

It is difficult to assess the approaches taken by Wohlmann to his clinical practice. First, there is the problem of assessing his diagnoses. He recorded in his introduction to Mineral waters and spas of New Zealand, ${ }^{48}$ for example, that a "departure has been made from the system of nomenclature hitherto considered orthodox ... the term 'chronic rheumatism' has been almost eliminated, and the great bulk of cases usually labelled under that heading have been put down as gout."

The second problem is that of determining whether the therapies and procedures he recommended were of value. Even now, the effects of immersion in various spa waters are very poorly understood. O'Hare and his colleagues noted in 1985 that "despite fierce debate about its efficacy there has been little scientific evaluation about the effect of immersion in mineral waters". 49 These authors, however, did demonstrate the profound physiological effects on urinary excretion and the blood picture: both features were recognized by Wohlmann, and the latter was the subject of some of his personal studies. O'Hare and his colleagues failed, however, to find any effects attributable to immersion in mineral water per se; it appears that, as long as the depth and temperature of the water are the same, the renal, haematological, and cardiac changes with immersion occur to the same degree in both mineral water and tap water. It is small wonder, therefore, that confusion over the value of spa therapy existed in Wohlmann's time, when controlled clinical studies were only in their infancy. However, studies of the physiology of immersion, which has attracted attention as a model of weightlessness for experiments in training of astronauts, only address part of spa therapy. The techniques used by spa physicians also included ingestion of the various waters and such physical techniques as electrical therapy, which have not been adequately investigated scientifically.

Although spa therapy has ancient origins, it was not until the latter part of the nineteenth century that attempts were made to assess its value. In 1896 the British Balneological and Climatological Society was founded by Dr Samuel Hyde, with the object of not only uniting the practitioners in the various British spas, "but to promote amongst them the pursuit of scientific medicine and the highest ideals in practice". 50 The enthusiasm for spa treatment among the more affluent members of society was also dependent upon recommendations by private physicians in London like Sir Hermann Weber and Dr F. Parkes Weber (who was instrumental in

\footnotetext{
48 Op. cit., note 36 above.

49 J. P. O'Hare, A. Heywood and others, 'Observations on the effects of immersion in Bath Spa water', Br. med. J., 1985, 291: 1747-51.

${ }^{\text {so }}$ H. W. Davies, 'Problems and opportunities for research in spa treatment', Samuel Hyde Memorial Lecture, Proc. R. Soc. Med., 1928, 21: 583-8.
} 


\section{Ralph H. Johnson}

Wohlmann's appointment), who together wrote a monograph on what spa was best for what condition. ${ }^{51}$ The increased interest in balneology and climatology led to the formation of the Balneological and Climatological Section of the Royal Society of Medicine in 1909. The proceedings of the Section and its predecessor, the Society, provide evidence about changes in medical thinking related to spa practice in the UK over the period that Wohlmann was working in, and developing, the resort at Rotorua. Many of the early presentations to both the Society and the Royal Society of Medicine Section described various resorts and changes in weather. The first paper, by $\mathbf{R}$. Fortescue Fox, on the value of medicinal baths for invalid soldiers, appeared in 1915, when similar developments were beginning to take place in Rotorua. Fortescue Fox wrote:

For an account of the known reactions of the body in various conditions of disorder and disease to medical baths, reference must be made to works upon hydrology ... these reactions have been recognised and defined with some precision and many of them follow with almost mathematical accuracy the slightest variation in temperature, duration, or other characters of the bath ... bath treatments require skill not only in their choice but in their administration. ${ }^{52}$

In spite of such claims, there was little questioning or scientific study of the value of the various procedures. The first important paper that initiated an analytical approach to the value of spa therapy was that of Wilfred Edgecombe, in $1924{ }^{53}$ It is surprising that such an iconoclastic paper should have been the Presidential Address of the section; its author was, moreover, a physician from Harrogate, where the approach to spa therapy might be expected to have been conservative. He examined information given in the British Spa Federation's handbook The spas of Britain, which described the nine major British spas, including Bath, where Wohlmann had worked. After drawing attention to the various disorders that could be treated in the spas, according to their literature, Edgecombe pointed out that either of two conclusions could be drawn, given so much overlap, in spite of the wide differences between the waters. Perhaps the claims made were extravagant and could not be substantiated, in which case they stood urgently in need of revision, or they were, in the main, true, in which case it must follow there could be nothing specific about a particular spa's treatment. His own conclusion was that there must be "nothing truly specific in the treatment of any disorders at any one of the spas" and that "it cannot be said that any factors have been established even remotely resembling specific action in any one disease". 53 He drew attention to the paucity of adequate experimentation related to clinical value. If spa treatment were beneficial in the variety of diseases for which its value was claimed, this must, he pointed out, depend upon certain general principles upon which it was founded.

Writing ten years earlier, Wohlmann also concluded that cure at a watering place depended upon factors other than water. ${ }^{54} \mathrm{He}$ drew attention to the importance of

${ }^{51}$ Op. cit., note 15 above.

52 R. F. Fox, 'The value of medical baths for invalid soldiers', Proc. R. Soc. Med., 1915, 7: 47-58.

${ }^{53} \mathrm{~W}$. Edgecombe, 'The principles of spa therapy in Great Britain', ibid., 1925, 18: 2-12.

54 Wohlmann, op. cit., note 36 above. 
Plate 18. The only photograph of Arthur Stanley Wohlmann that has been traced: from the New Zealand Illustrated Magazine, October 1902.
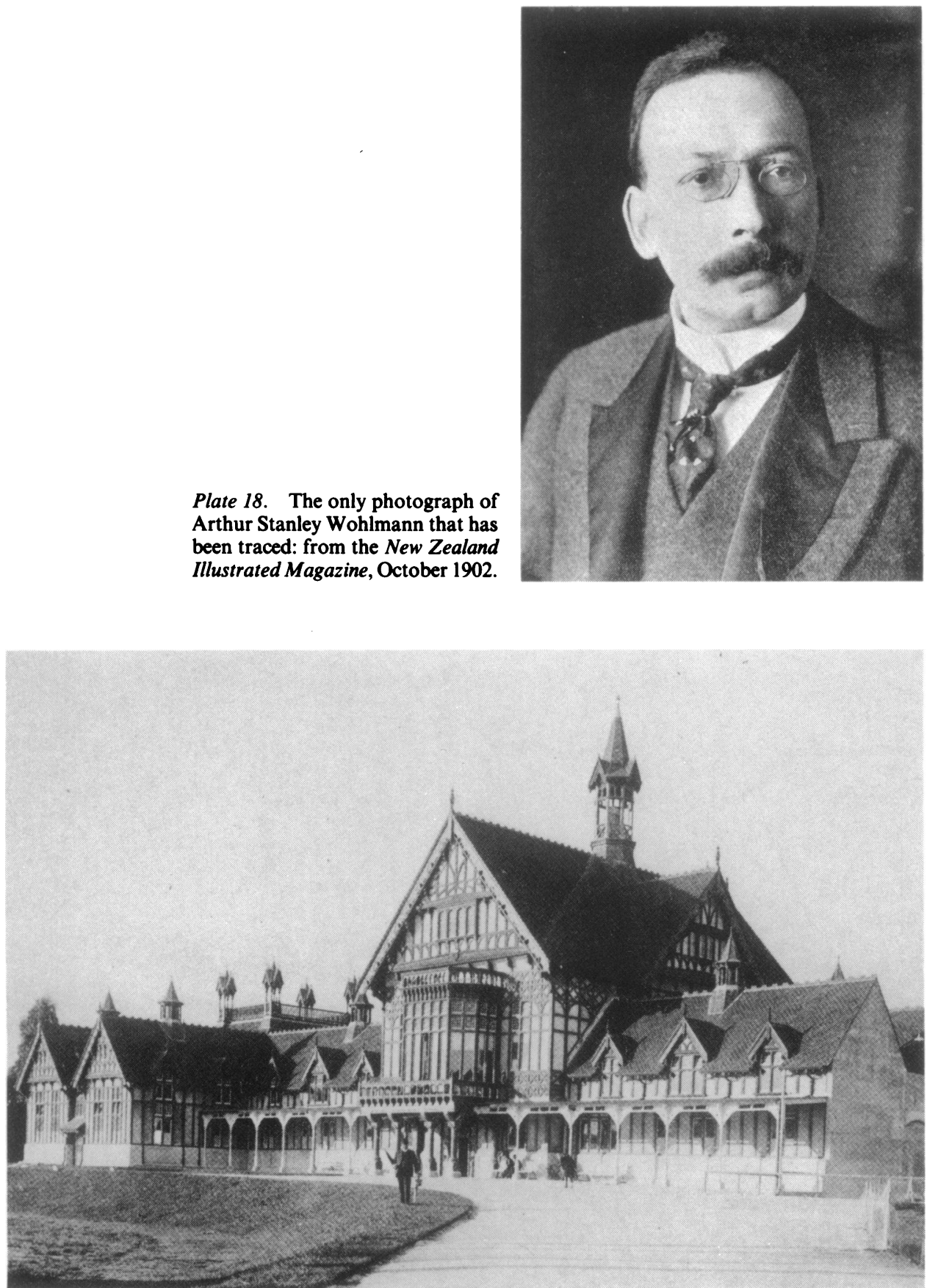

Plate 19. The Rotorua bath house in 1909, before the addition of a south transept in 1911. The building was opened when unfinished in August 1908 by the Premier, Sir Joseph Ward, and Admiral Sperry of the American Fleet. (Photograph by Muir and Moodie, by kind permission of the Rotorua Museum.) 


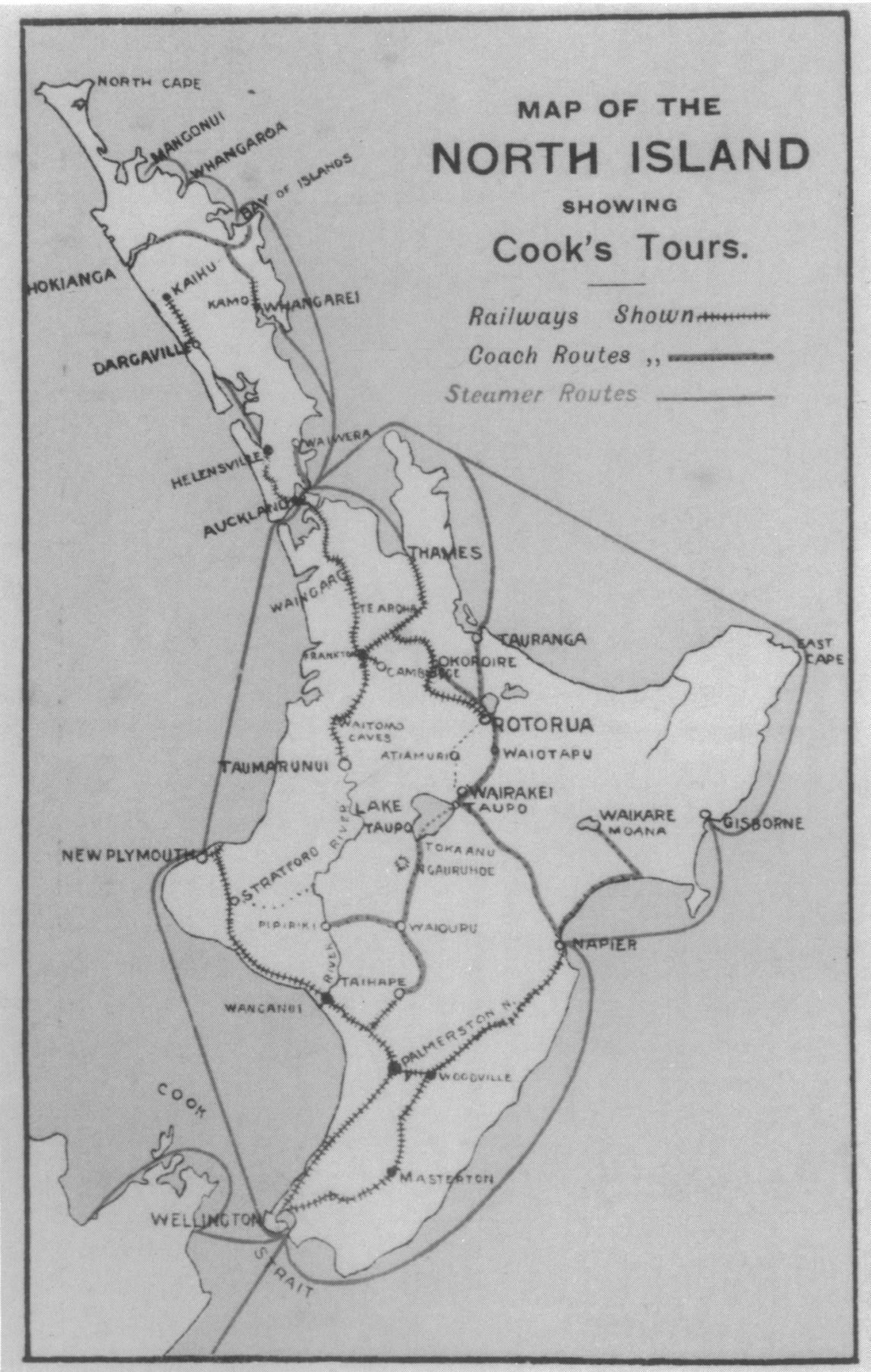

Plate 20. Map of North Island, New Zealand showing tours recommended by Thomas Cook \& Son. (From New Zealand as a tourist and health resort, 5th ed., 1905.) 


\section{The first Government Balneologist in New Zealand}

accessory physical treatment, diet and regulation of habits, change of environment, and suggestion. When he restated these general principles in his 1921 book, ${ }^{55}$ he added the importance also of rest.

Edgecombe's paper foreshadowed similar articles over the succeeding five years. Crookshank in 1926 wrote:

we are no nearer the ultimate understanding of curative processes initiated at Bath or Harrogate than we were one hundred years ago ... even if we say that the sceptics who declare the whole effect of Spa treatment to be psychological are right, what is gained? ${ }^{56}$

George Bernard Shaw also drew cynical attention to the value of spa therapy and claims for it. ${ }^{57}$ Calthrop pointed out, in 1928 , that many questions still awaited an answer. For example:

Can we obtain all the effects produced by thermal or mineral water baths by the varied use of fresh water baths? Can we get the same effects by drinking fresh plain water as are produced by the various thermal waters? ${ }^{58}$

He appealed for research into these and other hydrological problems. The dogmas of Wohlmann's time were being succeeded by uncertainty. It was noted that many spas had set up laboratories but there was still very limited use of such new procedures as electrocardiography. Papers still appeared frequently on various regions as Health Resorts, including London(!) and Torquay. It was becoming obvious that the Royal Society of Medicine Section was not based scientifically enough. Without any comment in the Journal it was renamed, in 1931, the "Section of Physical Medicine" and thereafter addressed more clinical problems than had been the case throughout the previous 20 years.

It is in the context of this background that one must assess Wohlmann's analysis of his patients. In his 1914 book he analysed his in-patients from $1911 .{ }^{59} \mathrm{He}$ recorded that there was improvement in no fewer than 536 out of a total of 593 patients. Major improvement was recorded in rheumatic cases, and in infections such as gonorrhoeal or tubercular arthritis. Diseases of the nervous system also showed improvement; one major group (50 cases) suffered from neurasthenia, a diagnosis frequently used in the First World War, sometimes also called cardiac neurosis, which fell out of fashion subsequently. He also recorded blood-count studies that, typically enquiring, he had

\footnotetext{
55 Idem, op. cit., note 43 above.

${ }^{56}$ F. G. Crookshank, 'Airs, waters and places', Proc. $R$. Soc. Med., 1926, 19: 17-22.

${ }^{57}$ George Bernard Shaw, 'What is to be done with the doctors?', English Rev., Dec. 1917-March 1918, repr. Doctors' Delusions, 1931. In this article, Shaw was cynical about doctors' approaches to hydrotherapy: "Water cures or Hydropathics ... all these places are under a steady economic pressure which eventually and inevitably changes them into more or less expensive hotels ... 'The Hydro' ... at no stage of the process, from its inception in therapeutics to its culmination in golfing, does it come within the reach of the submerged nine-tenths." I am obliged to Michael Holroyd for this reference.

${ }^{58}$ L. C. E. Calthrop, 'The scientific bases of the practice of medical hydrology', Proc. R. Soc. Med., 1928, 21: 477-83.

59 Wohlmann, op. cit., note 36 above.
} 


\section{Ralph H. Johnson}

carried out personally. Regrettably, however, he did not critically examine his therapy and was inclined to accept popular views, for example the "supreme importance of the role of radioactivity in balneology", a theory which held sway for a few years around the beginning of the First World War.

There is no evidence that Wohlmann changed his views on the advantages of his thermal baths during the First World War but, as he began to work with invalid soldiers, his interests appear to have adapted. Although he continued to use the "ordinary methods of massage, electricity, exercises, baths and douches", he also became interested in physical medicine and particularly the development of mechanical supports for paralysed muscles. As already noted, he wrote a preliminary paper for the New Zealand Medical Journal in $1916,{ }^{60}$ and, in 1918, the first part (all that was published) of a text on military physical orthopaedics on his work in relation to gunshot wounds of nerves. ${ }^{61}$ This describes his careful neurological assessment of patients. He reviewed the neuro-anatomy of nerve lesions in detail. He was up-to-date in his quotation of the literature, however inadequate that may have been, and commented on papers from the British Medical Journal of the same year. Previously, in his book Mineral waters and spas of New Zealand ${ }^{62}$ he had quoted reports from the British Medical Journal and the Balneological Section of the Royal Society of Medicine of the year before. This is remarkable, allowing for the transport time for the journals to New Zealand and the probable publication time for the book.

\section{CONCLUSION}

This paper describes the enthusiasm of the first Government Balneologist in New Zealand to develop a therapeutic spa, Rotorua. It was not a success; and Rotorua's failure as an international spa resulted from several factors. In 1908 the main trunk line was completed between Auckland and Wellington, bypassing Rotorua. Travellers were less likely to travel south by train to Rotorua and then face a difficult journey over poor roads to rejoin the railway. Within months of the completion of the bath-house it was disfigured by discoloration of the plaster, which also frequently collapsed. Only five years later, the World War effectively put an end to tourist travel, and the Rotorua bath-house was used for the rehabilitation of soldiers.

Failure is generally poorly recorded in history books, and Arthur Stanley Wohlmann's story has been no exception. It nevertheless represents one of the first major attempts to bolster the economy of New Zealand through tourism at a time when spa treatment was looked upon as a major form of medical treatment, for those who could afford it. Wohlmann's techniques were similar to those being practised in British spas and he was ahead of many physicians in his attempts to analyse his therapy and publish his conclusions.

${ }^{60}$ Op. cit., note 37 above.

${ }^{61}$ Op. cit., note 38 above.

62 Op. cit., note 36 above. 